\title{
Monthly and Seasonal Variation of the Tropopause Pressure on the Middle East
}

\author{
Abdulhaleem Hussin Labban \\ Department of Meteorology, Faculty of Meteorology, Environment and Arid Land Agriculture, \\ King Abdulaziz University, Jeddah 21589, Saudi Arabia
}

\begin{abstract}
. tropopause is the natural boundary between two different atmospheric layers, that is, stratosphere and troposphere. However, both of these layers (stratosphere and troposphere) differs significantly in terms of various dynamical and chemical parameters (for example, temperature, pressure, water vapors, etc.). It is therefore necessary to study the tropopause in order to better understand the static and dynamic conditions of aforementioned atmospheric parameters. This study therefore highlights the monthly and seasonal variation of tropopause pressure over the Middle East region. For this, reanalysis data set of tropopause pressure over Middle-East through the period from 1948 to 2006 are acquired from National Centers for Environmental Prediction (NCEP). Average of monthly and seasonal tropopause pressure distribution over the study region are estimated and discussed. The results of the study show that the summer seasons and the first month of autumn season have similar tropopause pressure distribution over the study region. The results of the study also show that the distribution of tropopause pressure for summer season started as a short wave at the end of spring season. In addition, northern part of the study region has zonal distribution of tropopause pressure with the exception of summer season as well as for the first month of autumn season.
\end{abstract}

Keywords: Troposphere, Stratosphere, Tropopause, NCEP.

\section{Introduction}

The enhancement of greenhouse gases in the atmosphere has been conclusively proved by scientists (Degorska et al., 1996; Hsua et al., 2013; Mashat et al., 2016; Cho et al., 2016). In this context, the phenomena of global warming is real that forced us to study the climatic changes in respect of meteorological parameters (for example, precipitation, temperature, pressure). Several studies have been conducted taking into account of annual rainfall (for example, Sen and Prasad, 1991; Srivastava and Sinha, 1994; Srivastava et al., 1992, 1994; Subramaniam et al., 1992; Sinha and Srivastava, 2000), and maximum and minimum temperature trends (Sinha Ray et al.; 1997; De and Rajeevan, 1997; Srivastava, et al., 2000) over different parts of the world. In addition, several studies have also been conducted examining monthly and seasonal variations in temperature and height (for example, Shastry and Narasimham, 1966; Sharma, 1966; Sivaramakrishnan, 1986). However, very little research has been done considering tropopause characteristics in the atmosphere (Desikan et al., 1994; Schubert and Munteanu, 1988). This study focuses monthly and seasonal variations in tropopause pressure over the Middle East with the main emphasis over Kingdom of Saudi Arabia.

Atmosphere constitutes from five layers (troposphere, stratosphere, mesosphere, thermosphere, and exosphere) that further consists of different gasses (for example, 
$78 \%$ nitrogen, $21 \%$ oxygen, $0.9 \%$ argon, and $0.03 \%$ carbon dioxide) and water vapours which surrounds the earth. These layers have been apportioned with respect to temperature and pressure variations in the atmosphere. The lowest layer from the surface of the earth is troposphere that extends from 0 to $16 \mathrm{~km}$, the stratosphere extends from 16 to $50 \mathrm{~km}$, the mesosphere extends from 50 to $80 \mathrm{~km}$, the thermosphere extends from 80 to $640 \mathrm{~km}$, and the exosphere extends from 640 to $10000 \mathrm{~km}$. The role of the atmosphere is to drive air at different pressure systems and thereby controlling the weather system on earth (Angell, 1981; Bojkov and Fioletov; 1997, Gaffin et al., 2000; Hoinka, 1998, 1999). These atmospheric systems also have very interesting temperature variations. For example, in the troposphere, there is a positive lapse rate (temperature decrease with height) on the average whilst in the stratosphere, the temperature is nearly constant up to about 20 $\mathrm{km}$ and then increases with height (Sellers and Wen, 1988). It is the troposphere that contains nearly all the weather as we understand it, namely clouds, precipitation, and wind (Ramamurthy, 1976). On the other hand, stratosphere due to its stability is ideal for the smooth aircraft flying. However, the boundary surface between the two layers (troposphere and stratosphere) which is called tropopause represented the top of the layer acts as a layer that is suitable for mixing and heat transport due to convection. Thus, the temperature variations, as well as the pressure system governed in the tropopause, are very important in understanding the weather system. It is therefore important to discuss briefly tropopause region of the atmosphere particularly in the context of pressure.

The tropopause is the boundary surface between the troposphere and the stratosphere in the atmosphere. It is not horizontally constant and is lower (about $6 \mathrm{~km}$ ) over the poles and high (approximately $18 \mathrm{~km}$ ) over the equator (Wege and Claude, 1997). In addition, its height also varies with the season, in middle latitudes especially. For example, its height is lower in winter than in summer. The tropopause is the atmospheric zone where the rate of the lapse rate changes from the positive it behaves in the troposphere layer and then moves to the negative lapse rate in the stratosphere. Tropopause layer is characterized by a constant temperature in the entire layer. Jet streams (usually separates colder and warmer air masses) that play an important role in determining the weather, occur in the upper troposphere, just below the tropopause. In addition, the gradients that exist between centres of high and low pressure (anticyclones and cyclones respectively) and the modifying factor known as the Coriolis Effect also has major impacts on winds and thereby weather system. High jet stream wave amplitude is called meridional flow. Troughs with low pressure and ridges with high pressure characterize meridional flow, which increases the mixing of warm and cold air masses. Using the zonal component of the wind at pressure level $250 \mathrm{hPa}$, Athanasiadis et al., (2010) found that there are two continuous jet streams stretch zonally and spiral slightly toward the pole. Awad and Almazroui (2016) in their study have classified the outermost effect of the Red Sea Trough (RST) into three classes, western, central and eastern RST classes. They found that the core of the maximum wind at the $250 \mathrm{hPa}$ pressure level for the western RST was located over northern Libya and Egypt. For the central RST, the core of the maximum wind shifted eastward (in comparing with the position of the western RST) and was located over the northern Red Sea. Whilst for the eastern RST, the core of the maximum wind was located over the northern Arabian Peninsula. Therefore, generally, the maximum wind at the $250 \mathrm{hPa}$ level affected the northern Red Sea in all situations, and the highest wind followed the oscillation of the RST near the Red Sea. Mashat and Awad (2015) 
analyzed the widespread dust cases influenced the northern Arabian Peninsula and found four main patterns: western, eastern, northern and southern. They found that the maximum wind speed at the $250 \mathrm{hPa}$ level, accompany the western pattern, occurred over northern Africa (Libya and Egypt), over the northern Arabian Peninsula. This wind forming a trough over the Red Sea as well as forming a ridge over the Arabian Peninsula along with a trough over Iran. They also stated that for the eastern pattern, the wind speedcore was located over the northern Arabian Peninsula, Libya and Egypt. For the northern pattern, the maximum wind core occurred over Libya and Egypt as well as over the north Arabian Peninsula. For the southern pattern, the core of the maximum wind located over Libya and Egypt. A very little research has been done to investigate tropopause relationship with meteorological parameters (Sivaramakrishnan et al., 1972, Steinbrecht et al., 1998). For example, Srivastava et al., (2002) studied the seasonal variations and trends in the tropopause height over Indian stations. Their study confirmed significant linear association ship between tropopause height over Indian stations and sea surface temperature anomalies of east Pacific Ocean with sea surface leading by one year (Verma, 1980).

\section{Materials and Methods}

The data used in this study is retrieved from National Centers for Environmental Prediction/National Center for Atmospheric Research - NCEP/NCAR reanalysis project (Kalnay et al., 1996) for the period from 1948 to 2006. One of the main advantages of this reanalysis data is that model parameterizations and resolution are unchanged for the entire time period (frozen system) (Kalnay et al., 1996; Kistler et al., 2001). Thus, both, the reanalysis data of the past and the Climate Data Assimilation System for the future are using the same frozen system. Such an arrangement are very helpful for the researchers as it eliminates perceived climate jumps associated with changes in the data assimilation system. Another advantage of reanalysis data as compared with observational data is that it can deliver a complete gridded state estimate that for all variables at all grid points where observational data is not available (Namias and Clapp, 1951; Kistler et al., 2001). The spatial and temporal resolution of the girded data used in the current study is $2.5^{\circ} \times 2.5^{\circ}$ available for the period 0000 , 0600, 1200, and 1800 GMT.

In the present study, the average of the annual tropopause pressure for the period from 1948 to 2006 is calculated at each grid point. In addition, the average of tropopause pressure for each month of the year is also estimated for the entire data sets. The difference between the tropopause pressure for each month and the annual mean tropopause pressure is also calculated in this study.

The main objective of this study is to draw the features of tropopause pressure for different months as well as for different seasons of the year. In current research, the mean tropopause pressure iso-bar lines are drawn at intervals 98, 100, 102, 104, 108, 112, $116,120,130,150,180 \mathrm{hPa}$, while the annual mean intervals are drawn at intervals 102, 104, 108, 112, 116, 120, 130, 150, $180 \mathrm{hPa}$. Similarly, iso-lines of tropopause difference pressure (difference between the tropopause pressure for each month and the annual mean tropopause pressure) are drawn at intervals $50,-40,-30,-20,-18,-14,-10,-6,-4,-2,0,2$, 4, 6, 10, 15, 20, 30, $40 \mathrm{hPa}$.

\section{Results}

The distribution and the characteristics of annual mean, seasonal, and mean monthly tropopause pressure distribution over study area from the year 1948 to 2006 are discussed in this section. In addition, the percentage of deviation of each month with respect to annual mean is also discussed. 


\subsection{Mean Tropopause Pressure}

The annual mean distribution of tropopause pressure is shown in Fig. 1. It is evident from Fig. 1 that there are two prominent areas for annual mean distribution of tropopause pressure. The first area north of $22^{\circ} \mathrm{N}$ where the tropopause pressure distributed on zonal feature with a small north shift of iso-lines on the east. The second area is south of $22^{\circ} \mathrm{N}$ where the tropopause pressure distributed on the circular feature, for example, the isobaric line $102 \mathrm{hPa}$ are noticeable. It is also evident from Fig. 1 that the tropopause pressure magnitude and gradient increase towards the north. For simplicity, if pressure is interpreted as height then it is clear that the tropopause height decreases toward the north.

\subsubsection{Winter season}

The distribution of tropopause pressure for the winter months (December, January, and February) are shown in Fig. 2 (a, b, c). It is evident from Fig. 2 (a, b, c) that the general distribution of tropopause pressure for all three winter months is more or less similar. In addition, the general distribution of tropopause pressure for winter months resembled with annual mean distribution with slightly higher gradient and larger range. For example, the winter months ranges between $98 \mathrm{hPa}$ on the south to $180 \mathrm{hPa}$ on the north, while for annual mean distribution it ranges between $102 \mathrm{hPa}$ on the south and $150 \mathrm{hPa}$ on the north. Also, the range increases as winter month advance from the month of December to the month of February. Similarly, the difference of tropopause pressure distribution for the study area is shown in Fig. $3(\mathrm{a}, \mathrm{b}, \mathrm{c})$. The positive and negative difference of tropopause pressure distribution over the area of interest as evident in Fig. 3 (a, b, c) indicates that each month of the winter season (December, January, and February) has higher pressure in the north and relatively lower tropopause pressure in the south of the study area. In addition, the positive value and the gradient in the north area increase as winter months advance. The winter months difference isobars shifted towards relatively south at the eastern region of the interesting area. The wavy shape is clear at south part over the water area of Red Sea and in the interior land of Arabian Peninsula.

\subsubsection{Spring season}

The distribution of tropopause pressure for the spring months (March, April, and May) are shown in Fig. 4 (a, b, c). It is evident from Fig. $4(a, b, c)$ that the horizontal gradient for the spring season is mostly concentrated north of $22^{\circ} \mathrm{N}$ and is weak in the south of $22^{\circ} \mathrm{N}$. It is also evident from Fig. $4(a, b, c)$ that the horizontal gradient of the tropopause pressure decreases as the spring months advance from March to May. It can also be noted from Fig. 4 $(a, b, c)$ that the horizontal orientation of the tropopause isobars shifts towards north on the east of the study area as the spring months advances from March to May. Similarly, the minimum value of tropopause pressure during the spring season increases from $98 \mathrm{hPa}$ in March to $102 \mathrm{hPa}$ in May while the maximum value of tropopause pressure during the spring season decreases from $180 \mathrm{hPa}$ to $150 \mathrm{hPa}$.

Similarly, the difference of tropopause pressure distribution for the spring season over study area is shown in Fig. 5 (a, b, c). The gradient and magnitude of the tropopause pressure during spring months decrease as season month advance from March to May. Also, the wavy shape of the difference of tropopause pressure distribution during the month of March, as evident in Fig. 5a, are changing to circulation shape during the months of April and May especially on the eastern region of the study area. The maximum negative difference of tropopause pressure distribution during the month of May is concentrated at the northeast of the study area 
while during the months of March and April the same pressure is concentrated over the south. The circulation feature of the difference of tropopause pressure distribution during the month of March are much clear in Fig. 5a while the wavy shape of the difference of tropopause pressure distribution which exists in south of study region during the months of March (Fig. 5a) and April (Fig. 5b) are spread away to north during the month of May (Fig. 5c).

a) MEAN from 1948-2006 TROP-PRES

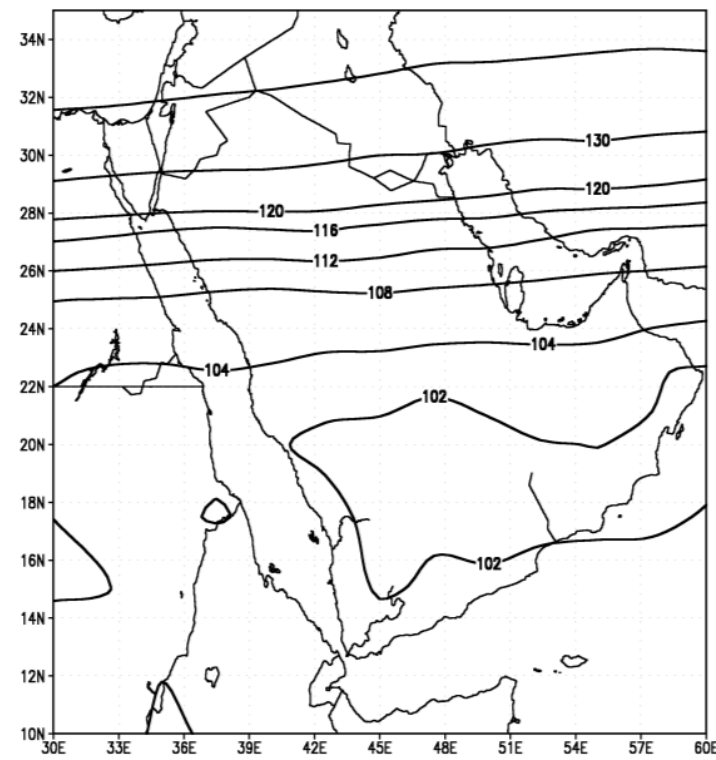

Fig.1. The average of the annual tropopause pressure over the period from 1948 to 2006 .
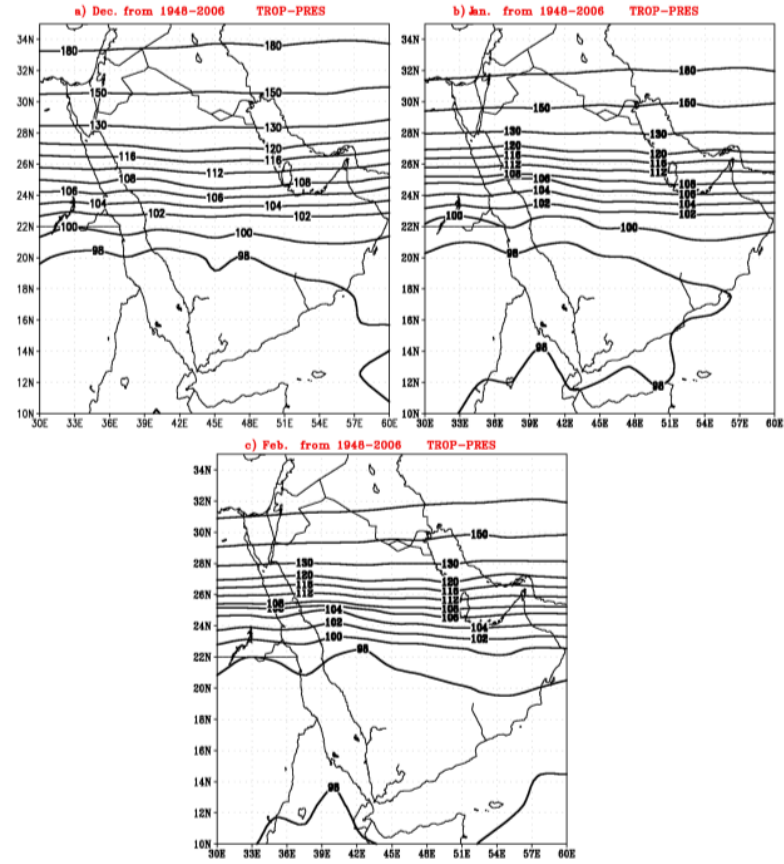

Fig. 2. The mean tropopause pressure in winter months for the period from 1948 to 2006. 


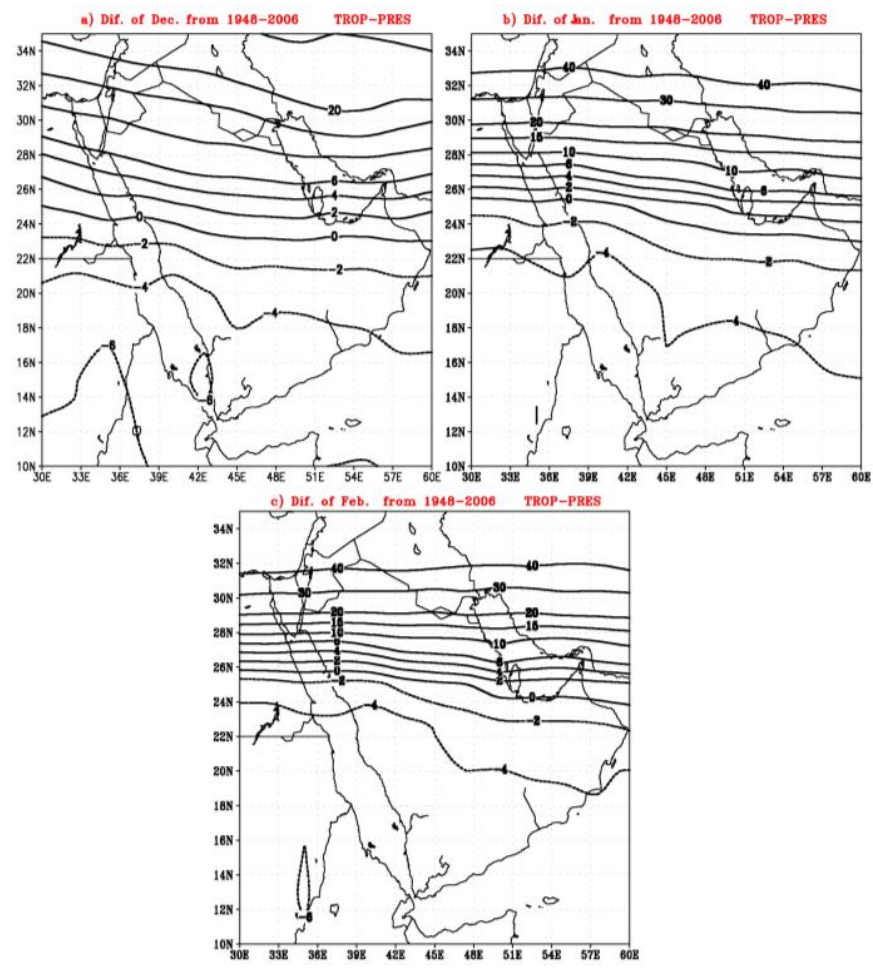

Fig. 3. The difference of mean tropopause pressure in winter months from the average of the annual tropopause pressure for the period from 1948 to 2006.

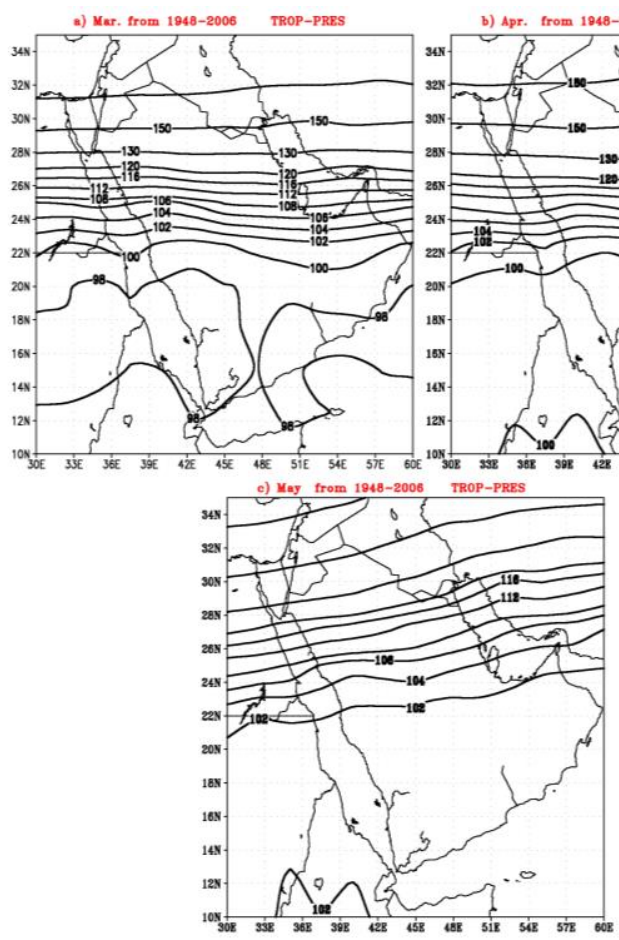

Fig. 4. The mean tropopause pressure in the spring months for the period from 1948 to 2006. 


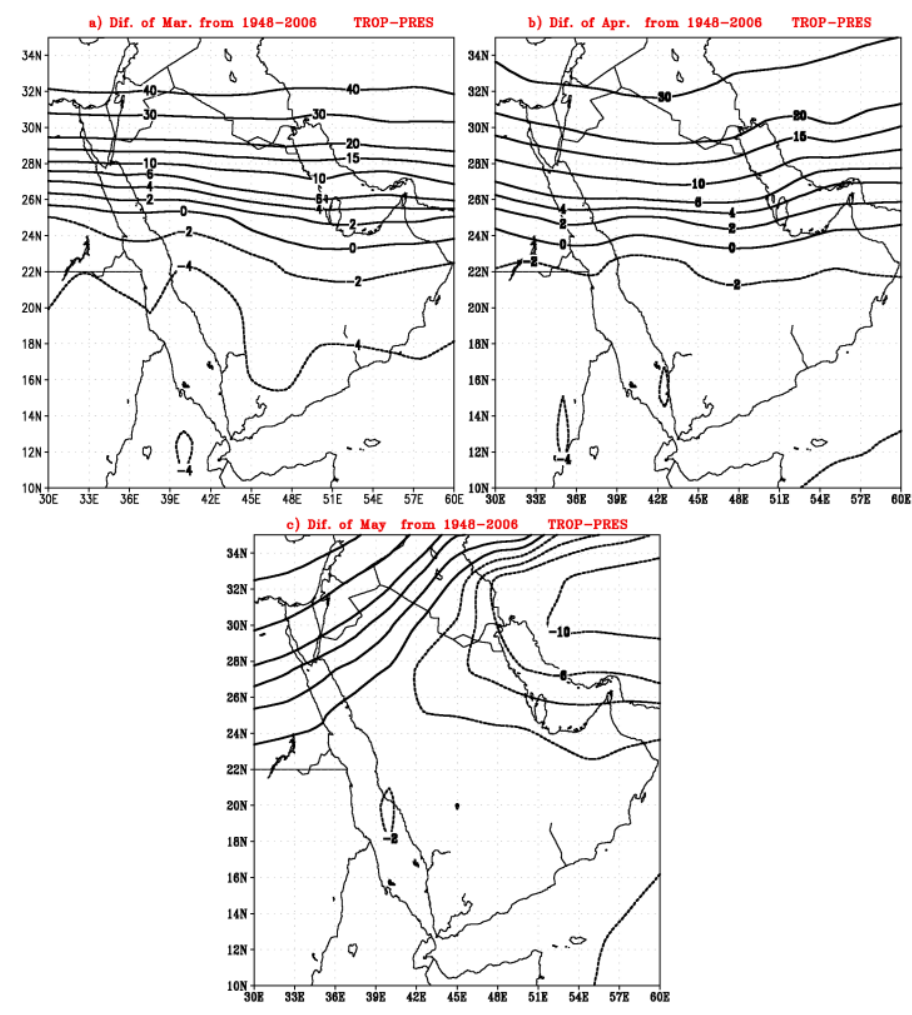

Fig. 5. The difference of mean tropopause pressure in spring months from the average of the annual tropopause pressure for the period from 1948 to 2006.

\subsubsection{Summer season}

The distribution of tropopause pressure for the summer months (June, July, and August) are shown in Fig. $6(a, b, c)$. It is evident from Fig. 6 ( $a, b, c)$ that, in contrast to the winter and spring seasons, the minimum value of the horizontal gradient for the summer season is mostly concentrated at mideast of the study area. It is also evident from Fig. $6(a, b, c)$ that the summer season tropopause pressure distribution has a wavy shape over entire study region which is deeper over the Red Sea area. The minimum tropopause pressure exists for the month of July with the value $98 \mathrm{hPa}$ which reaches to $100 \mathrm{hPa}$ for the remaining two months (June and August). In contrary to the winter and spring seasons, the horizontal gradient of tropopause pressure increases over the southern region of the study area during summer season. In addition, the horizontal gradient of tropopause pressure decreases from June to August.

Similarly, the difference of tropopause pressure distribution for the summer season over study area is shown in Fig. 7 (a, b, c). Once again, in contrast to winter and spring seasons, the distribution of negative tropopause difference is over the northern part of the study areas while the distribution of positive tropopause difference is over the southern region of the study area during the summer season. The gradient and magnitude of the tropopause pressure during summer months increase as season months advance from June to August. Also, the wavy shape of the difference of tropopause pressure distribution during the month of August is 
changing to circulation shape (as evident in Fig. 7c) and moved to the interior area of the study region.

\subsubsection{Autumn season}

The distribution of tropopause pressure for the autumn months (September, October, and November) are shown in Fig. 8 (a, b, c). It is evident from Fig. $8(\mathrm{a}, \mathrm{b}, \mathrm{c})$ that, the range of tropopause pressure for the autumn season increases from September (Fig. 8a) to November (Fig. 8c) while the wavy shape of the distribution of tropopause pressure for autumn season decreases from September to November. In addition, the wavy shape is very weak over the northern region of the study area and is concentrated over the south Red Sea and Arabian Gulf. It is also evident from Fig. $8(a, b, c)$ that, the distribution of tropopause pressure "at various levels for autumn months" is affected by both, the summer season and winter season. For example, the distribution of tropopause pressure for the first month of autumn season, that is, for September is mainly dominated due to the distribution of tropopause pressure of summer season (Fig. 8a and Fig. 6a, 6b, 6c) while for the remaining two months of autumn season, that is, for the months of October and November the distribution of tropopause pressure is dominated due to the winter season tropopause pressure distribution (Fig. 8b, 8c and Fig. 2a, 2b, 2c). Similarly, the difference of tropopause pressure distribution for the autumn season over study area is shown in Fig. 9 (a, b, c). It is evident from Fig. 9 (a, b, c) that the gradient of the difference of tropopause pressure distribution decreasing from the first month of autumn to the last month, that is, from September to November. In addition, the difference of tropopause pressure distribution is negative at the start of the autumn season, especially at northern part, and ultimately converted into wave shaped and is positive over the entire study region during the month of November.

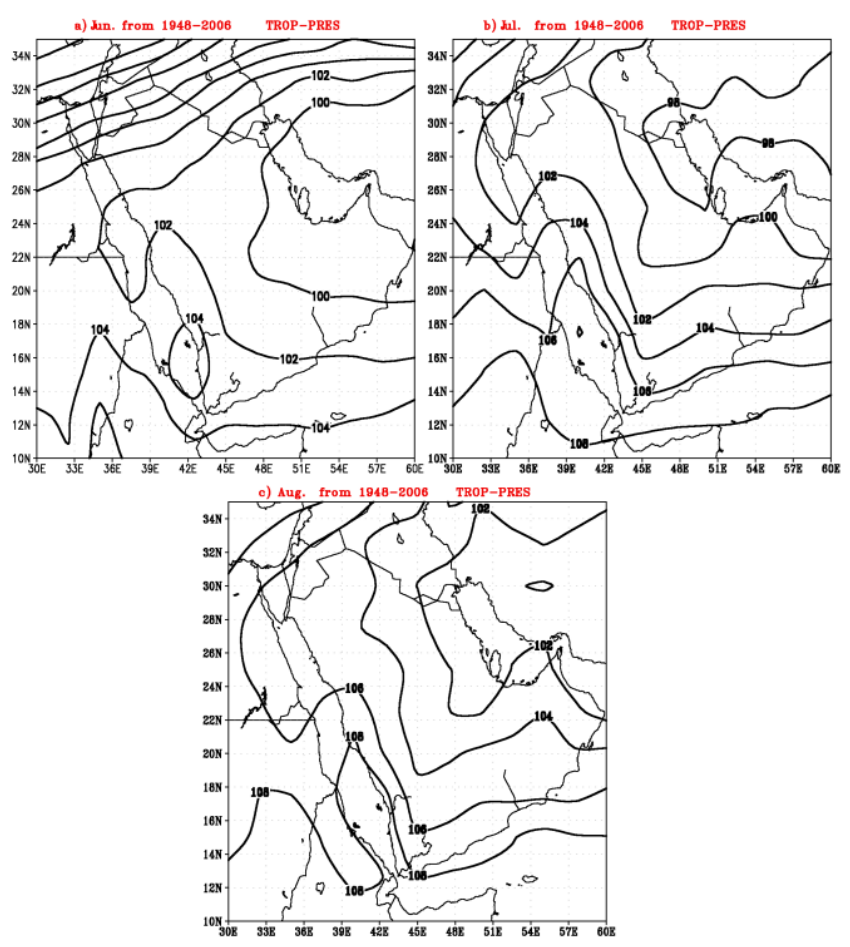

Fig. 6. The mean tropopause pressure in the summer months for the period from 1948 to 2006. 


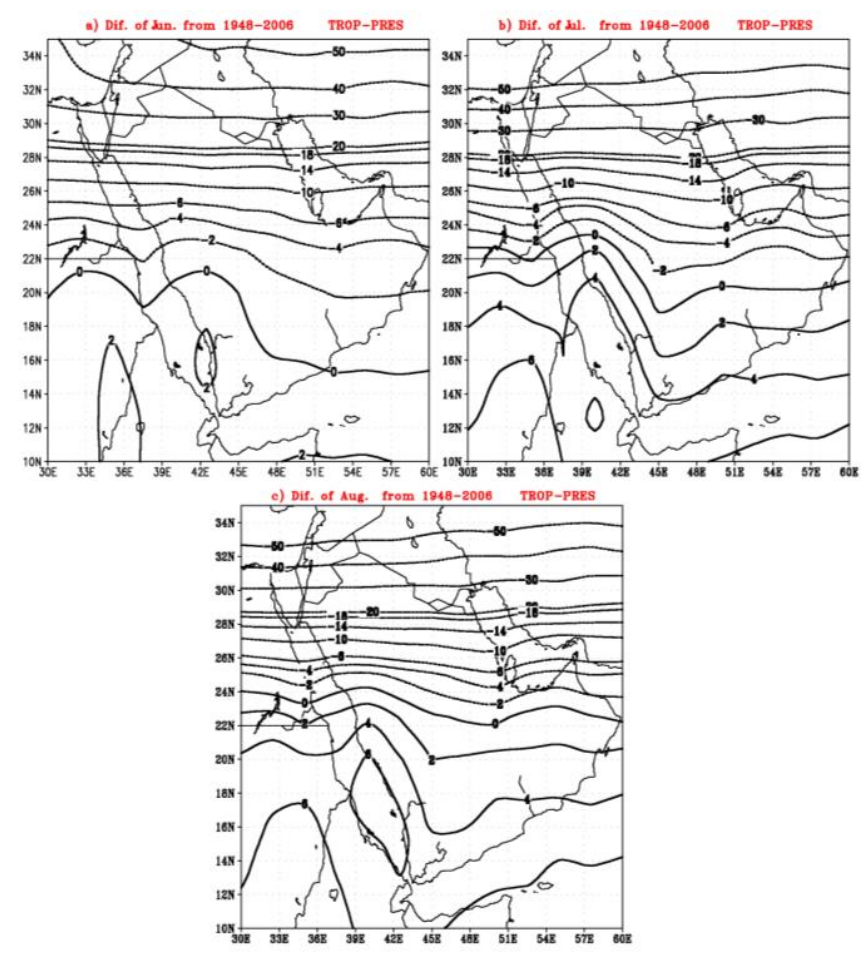

Fig. 7. The difference of mean tropopause pressure in summer months from the average of the annual tropopause pressure for the period from 1948 to 2006 .
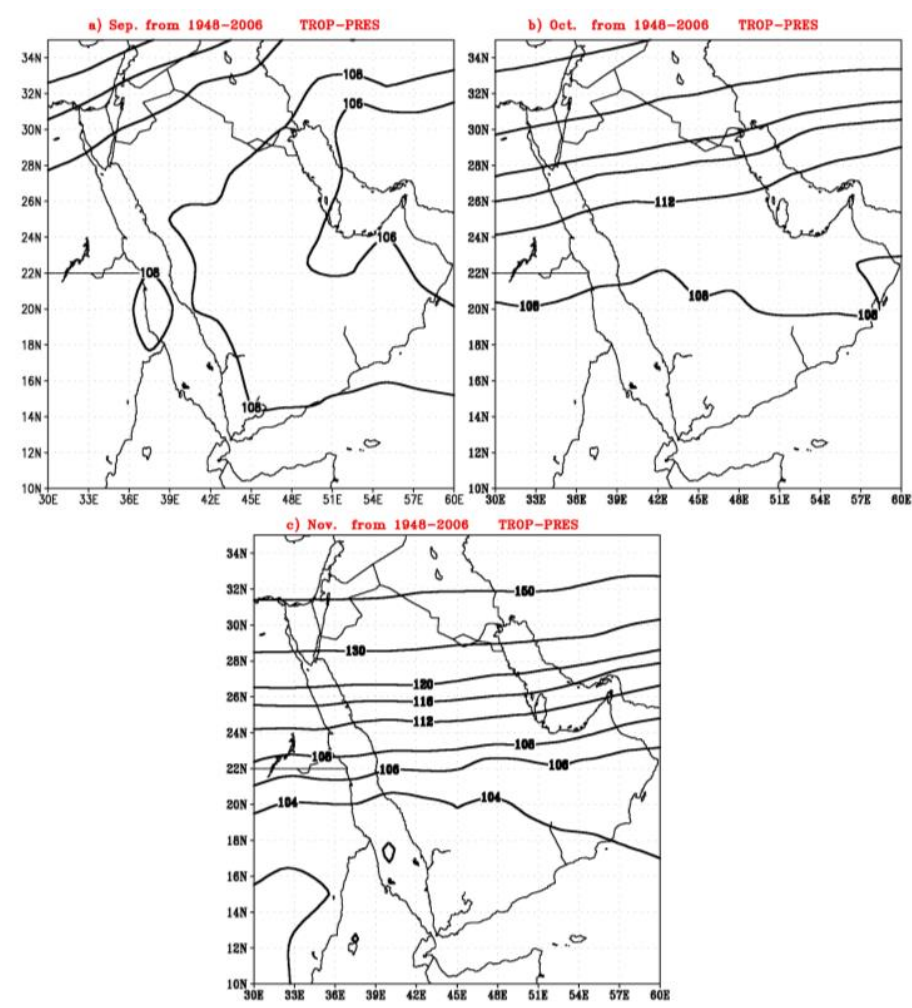

Fig. 8. The mean tropopause pressure in autumn months for the period from 1948 to 2006. 


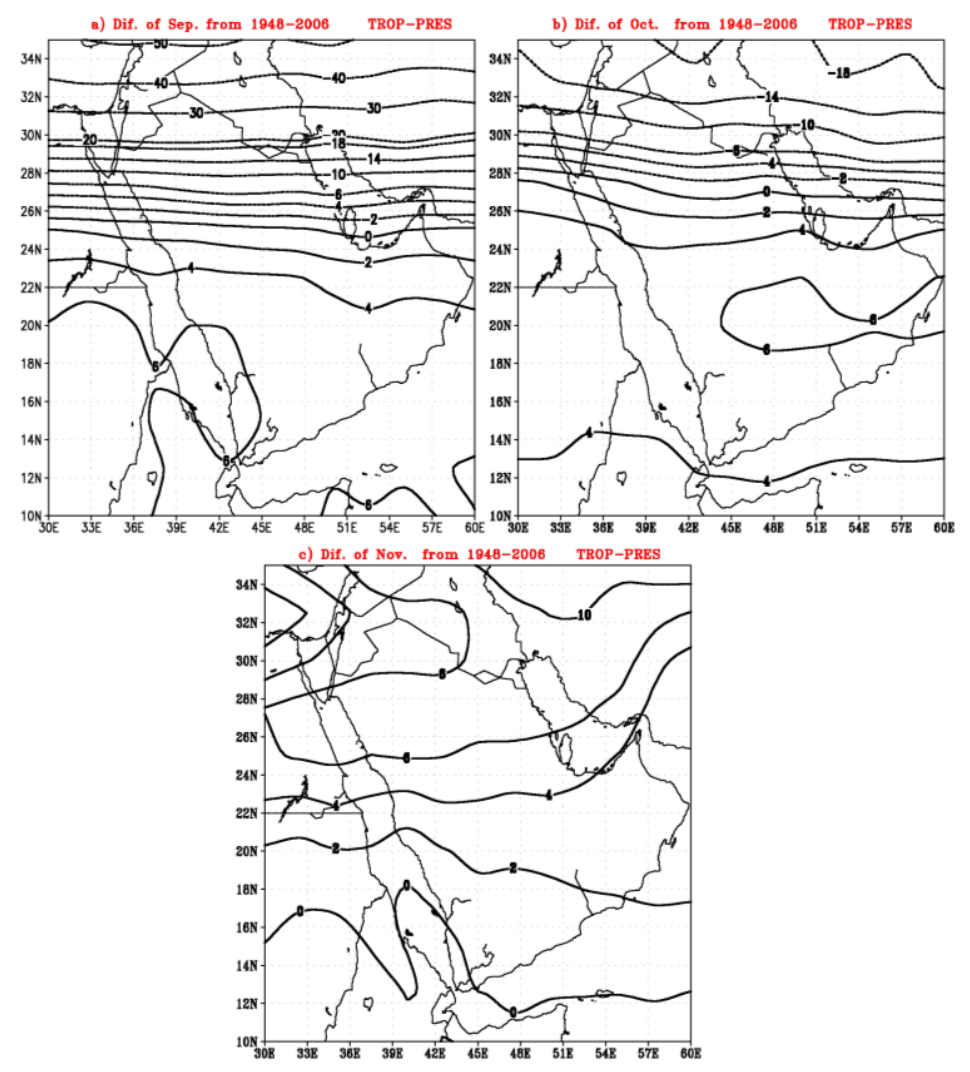

Fig. 9. The difference of mean tropopause pressure in autumn months from the average of the annual tropopause pressure for the period from 1948 to 2006.

\section{Discussions}

This study highlights the distribution of tropopause pressure over the Middle East from the year 1948 to 2006. In general, the results of the study reveal two distribution features of the tropopause pressure over the study region. The first distribution feature is for June, July, August, (summer season) and September (first month of autumn season) while the second distribution feature is for October, November (last two months of autumn season), December, January, February (winter season), March, April, and May (spring season). The minimum value of the tropopause pressure for the first distribution exists over the mideastern region of the study area while for the second distribution it exists over the southern region of the study area for the entire period. Similarly, the maximum value of the tropopause pressure for the first distribution exists over the southern region while for the second part it exists over the northern region of the study area. The results also revealed that the tropopause pressure distribution for the summer season as well as for the first month of autumn is prominent with wavy shape over the whole study area, however, for the second distribution, it becomes wavy only over the southern part of the study area.

The results of the study conclude that the winter season has the highest tropopause pressure range, while the last month of the summer season (July) and the first month of the autumn season (September) has lowest tropopause pressure range over the study region for the entire data set. In addition, the winter season has the strongest tropopause pressure over northern part while the 
tropopause pressure for the same season is lowest over the southern region of the study area.

The difference of tropopause pressure distribution for the spring season is affected by both the winter season and summer season. For example, the first two months of the spring features (March and April) are mainly affected by the winter features while the remaining one month (May) is affected by the summer features distribution. The positive value of the difference of tropopause pressure distribution for the summer season as well as for the first month of autumn season exists over the northern part of the study area while the negative values exist over southern part. This is in contrast to the remaining months of the year where positive value exists over southern part while negative value exists over the northern part of the study region.

\section{References}

Mashat, A.S., Assiri. M.E., Alamoudi, A.O., Khokhar, F., and Butt, M.J. (2016). Tropospheric Nitrogen Dioxide Measurements Over Saudi Arabia Using Ozone Monitoring Instrument Data. International Journal of Earth and Atmospheric Science, 3(2): 24-34.

Angell, J. K. (1981). "Comparison of variations in atmospheric quantities with sea surface temperature variations in the equatorial eastern Pacific", Mon. Wea. Rev., 109: 230-242.

Athanasiadis P.J., Wallace J.M. and Wettstein J.J. (2010). Patterns of wintertime jet stream variability and their relation to the storm tracks. Journal of Atmospheric Science, 67: 1361-1381. DOI: 10.1175/2009JAS3270.1.

Awad. A.M. and Almazroui, M. (2016). Climatology of the winter Red Sea Trough. Atmospheric Research, 182: 2029. DOI: 10.1016/j.atmosres.2016.07.019.

Bojkov, R. D. and Fioletov, V. E. (1997). "Changes of the lower stratospheric ozone over Europe and Canada", $J$. Geophys. Res., 102: 337-1347.

Cho, S.H., Tanaka, K., Wu, J., Robert, R.K. and Kim, T. (2016). Effects of nuclear power plant shutdowns on electricity consumption and greenhouse gas emissions after the Tohoku Earthquake. Energy Economics, 55: 223-233.

De, U. S. and Rajeevan, M. (1997). "Identification of anthropogenic climate change: A review", Vayu Mandal, 1\&2: 2-13.

Degorska, M., Kryszin, J. and Rajewska-Wiech, B. (1996). "Total ozone deficiencies at northern mid-latitudes during the summer season", paper presented at XVIII
Quadrennial Ozone Symposion, L'Aquila, Italy, 12-21 September, 1996.

Desikan, V., Jayaraman, K. and Bhagwat, S. P. (1994). "Terrestrial radiant energy exchanges across tropopause over Pune", Mausam, 45(4): 361-368.

Gaffin Dian, J., Sargent, M.A., Habermann, R.E. and Lanzante John, R. (2000). "Sensitivity of tropospheric and stratospheric temperature trends to Radiosonde Data quality", J. Climate, 13(10): 1776-1796.

Hoinka, K. P. (1999). "Temperature, Humidity and Wind at the Global Tropopause", Mon. Wea. Rev., 127(10): 22482265.

Hoinka, K. P. (1998). "Statistics of the global tropopause pressure", Mon. Wea. Rev., 126: 3303-3325.

Hsua A., Reubenb A., Shindellc D., de Sherbinind A. and Levyd M. (2013) Toward the next generation of air quality monitoring indicators. Atmospheric Environment, 80:561-570.

Kalnay, E., M. Kanamitsu, R. Kistler, W. Collins, D. Deaven, L. Gandin, M. Iredell, S. Saha, G. White, J. Woollen, Y. Zhu, M. Chelliah, W. Ebisuzaki, W. Higgins, J. Janowiak, K.C. Mo, C. Ropelewski, J. Wang, A. Leetma, R. Reynolds, R. Jenne and D. Joseph. (1996). The NCEP/NCAR 40-Year Reanalysis Project. Bull. Amer. Meteor. Soc., 77: 437-471.

Kistler, R., Collins, W., Saha, S., White, G., Woollen, J., Kalnay, E., Chelliah, M., Ebisuzaki, w., Kanamitsu, M. and kousky, V. (2001). The NCEP-NCAR 50-year reanalysis: Monthly means CD-ROM and documentation. Bulletin of the American Meteorological Society, 82: 247267.

Mashat, A.S. and Awad, A.M. (2015). Synoptic characteristics of the primary widespread winter dust patterns over the northern Arabian Peninsula. Air Quality Atmospheric Health, DOI 10.1007/s11869-015-0357-0.

Namias, J. and Clapp, P. E. (1951). "Observational studies of general circulation patterns", Compendium of Meteorology, T.F. Malone, Ed., Amer. Meteor. Soc., 551567.

Ramamurthy, K. (1976). Water vapour mixing ratio in the troposphere and its influence on the tropopause over India and neighbourhood, Indian J. Met. Hydro. \& Geophys., 27(3): 275-284.

Schubert, S. and Munteanu, M. (1988). "An analysis of tropopause pressure and total ozone correlations", Mon. Wea. Rev., 116: 569-582.

Sellers, W. D. and Wen Liu (1988). "Temperature patterns and trends in the upper troposphere and lower stratosphere", J. Climate, $\mathbf{1}$.

Sen Roy, N. and Prasad, K. (1991). "Climate change and global scientific response”, Vayu Mandal, 21(3\&4): 69-82.

Sharma, K. K. (1966). "A study of annual oscillations of tropopause over India”, Indian J. Met. Geophys., 17(3): 479-480.

Shastry, P. S. N. and Narasimham, A. L. (1966). "Some characteristics of tropopause over India", Indian J. Met. Geophys., 17(4): 567-572. 
Sinha Ray, K. C. and Srivastava, A. K. (2000). "Is there any change in extreme events like heavy rainfall?", Current Science, 79(2): 155-158.

Sinha Ray, K. C., Mukhopadhyay, R. K. and Chaudhury, S. K. (1997). "Trends in maximum, minimum temperature and sea level pressure over India", Presented in INTROMET 1997 held at IIT, New Delhi during 2-5 December 1997.

Sivaramakrishnan, M.V., Mokashi, R.Y. and Parameswaran, N. V. (1972). "A study of tropopause over India”, Prepublished Sci. Rep. No. 171.

Sivaramakrishnan, T.R. (1986). “Tropopause over Dibrugarh", Mausam, 37(1): 136-138.

Srivastava, A. K., Sinha Ray, K. C. and De, U. S. (2000). "Trends in the frequency of cyclonic disturbances and their intensification over Indian seas", Mausam, 51, 2: 113-118.

Srivastava, H. N. and Sinha Ray, K.C. (1994). "Climate Change Scenario Global and National Perspective", Vayu Mandal, 3\&4: 41-50.

Srivastava, H. N., Dewan, B. N., Dikshit, S. K., Prakasa Rao, G. S., Singh, S. S. and Rao, K. R. (1992). "Decadal trends in climate over India", Mausam, 43(1): 7-20.
Srivastava, H. N., Sinha Ray, K. C., Dikshit, S. K. and Mukhopadhyay, R. K. (1994). "Trends in rainfall and radiation over India", Presented in: TROPMET - 1994.

Srivastava, A. K., Sinha, K. C. and Kulkarni, R. (2002). Seasonal variation trend in the tropopause height/temperature over Indian stations and its modulation by SST anomalies of East Pacific Ocean, Mausam, 53(4): 439-446

Steinbrecht, W., Claude, H. and Kohler, U. (1998). "Correlation between tropopause height and total ozone: Implications for long-term changes", J. Geo. Res., 103: 19.183-19.192.

Subramaniam, S. K., Palande, S. V., Dewan, B. N., Dikshit, S. K. and Joseph, L. (1992). "Trends and periodicities in sub-divisional rainfall”, Mausam, 43, 1: 77-86.

Verma, R. K. (1980). "Importance of upper tropospheric anomalies for long-range forecasting of Indian summer monsoon activity", Mon. Wea. Rev., 108: 230-233.

Wege, K. and Claude, H. (1997). "Uber Zusammenhange zwischen stratospharischem Ozon und meteorologischen Parametern mit Folgerungen fur die Zeitraume nach den Ausbruchen von El Chinchon und Pinatubo", Meteorol. S., 6: $73-87$. 


\section{التغير الثهري والموسي لضغط التروبوبوز في الثرق الأوسط}

\section{عبد الحليم حسين لبان}

قسم الأرصاد، كلية الأرصاد والبيئة وزراة الدناطق الجافة، جامعة الملك عبد العزيز، جدة 1019 ا ، المدلكة العربية السعودية

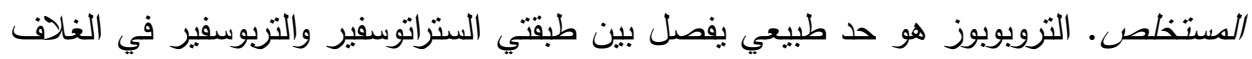
الجوي. ومع ذللك، فإن كلا هاتين الطبقتين (الستراتوسفير والتربوسفير) يختلفان بشكل كبير من حيث الخصائص الديناميكية والكيميائية (على سبيل المثال، درجة الحرارة والضغط وبخار الماء وما إلى ذلك). ولذلك فمن الواضح أن دراسة التروبوبوز مهم للوصول إلى فهم أفضل للظروف الساكنة والديناميكية لهذه العناصر • تسلط هذه الدراسة الضوء على التباين الثهري والموسمي لضغوط التروبوبوز في منطقة الثرق الأوسط. ولهذا، تم الحصول على مجموعة بيانات إعادة

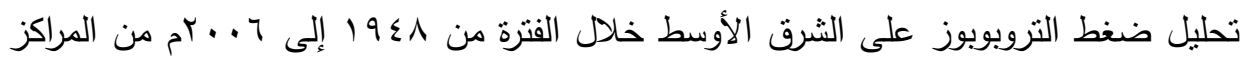
الوطنية للتنبؤ البيئي (NCEP). نم تقدير منوسط نوزيع ضغط التروبوبوز الثهري والموسمي على منطقة الدراسة ومناقتنه. تظهر النتائج أن مواسم الصيف والثهر الأول من فصل الخريف

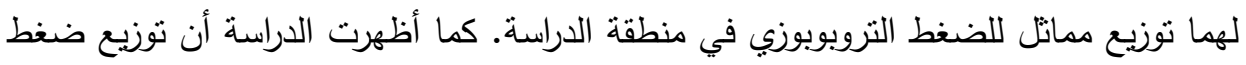
التروبوبوز لموسم الصيف بدأ كموجة قصبرة في نهاية فصل الربيع. بالإضافة إلى ذلك، يحتوي

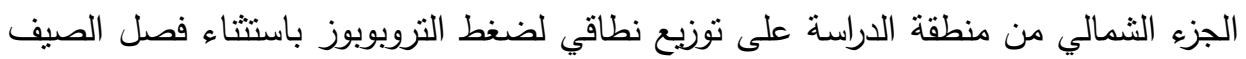
وكذلك الثهر الأول من فصل الخريف. منس النه كلمات ففتاحية : التربوسفير، الستراتوسفير، التروبوبوز، الثرق الأوسط. 
